\title{
Continued decline and conservation needs of the Endangered Mauritius olive white-eye Zosterops chloronothos
}

\author{
Rina Nichols, Lance Woolaver and Carl Jones
}

\begin{abstract}
The Mauritius olive white-eye Zosterops chloronothos is the least known of the eight threatened terrestrial bird species remaining on the island of Mauritius. The olive white-eye has declined drastically in numbers and distribution since 1975. Surveys carried out between 1998 and 2001 estimated that 93-148 pairs remained within an area of less than $25 \mathrm{~km}^{2}$. Most areas that held olive white-eye territories in 1975 supported considerably fewer territories in 2001. This decline is thought to have primarily been the result of deforestation and degradation of native habitat and intense nest
\end{abstract}

predation by introduced mammals. Declines have been more severe in areas dominated by native vegetation than they have been in areas that contained substantial amounts of exotic Cryptomeria and Pinus. The continued decline of the Mauritius olive white-eye is of critical concern and immediate species-specific conservation management is required for its survival.

Keywords Endangered, distribution, Mauritius olive white-eye, population status, Zosterops chloronothos.

\section{Introduction}

Mauritius, with an area of $1,865 \mathrm{~km}^{2}$, is the second largest of the Mascarene Islands in the south-west Indian Ocean, and has been severely degraded ecologically since the arrival of humans in the 1600s. Habitat loss and the introduction of a host of exotic flora and fauna has resulted in the extinction or endangerment of many of the endemic plant and animal species. At best, only $5 \%$ of forest with a significant native component remains (Safford, 1997a). Continued degradation of the remaining native forest is occurring rapidly as a result of introduced invasive plants and animals (Lorence \& Sussman, 1986). Of 671 native plant species, $46 \%$ of which are endemic to Mauritius, 76 are Extinct, 105 are Critically Endangered and 44 are Endangered (Page \& D'Argent, 1997; IUCN, 2003). All eight taxa of Mauritian palms are threatened with extinction (Maunder et al., 2002; IUCN, 2003).

Mauritian fauna have not fared much better. At least $50 \%$ of the endemic Mauritian vertebrate species, including 11 of the 21 endemic terrestrial bird species, have gone extinct since human colonization (Cheke,

Rina Nichols ${ }^{1}$ (Corresponding author), Lance Woolaver ${ }^{1}$ and Carl Jones Mauritian Wildlife Foundation, Avenue Bois des Billes, Black River, Mauritius, Indian Ocean. E-mail rinanichols@hotmail.com

${ }^{1}$ Current address: Wildlife Preservation Trust Canada, 120 King Street, Guelph, Ontario, N1E 4P8, Canada.

Received 3 January 2003. Revision requested 22 August 2003. Accepted 19 January 2004. 1987a). The Mauritius kestrel Falco punctatus, the pink pigeon Columba mayeri and the echo parakeet Psittacula echo, have been, or are currently, the focus of intensive management that has helped to substantially increase population numbers (Jones et al., 1992, 1995; Thorsen \& Jones, 1998). The remaining seven species are passerines, five of which are considered to be threatened (BirdLife International, 2000). Recent research suggests that some of the passerine species are still declining in distribution (R. Nichols, unpub. data; Nichols et al., 2002).

The Mauritius olive white-eye Zosterops chloronothos, the least known of all the Mauritian birds, is categorized as Endangered on the IUCN Red List (IUCN, 2003) and has recently been upgraded to Critically Endangered by BirdLife International (J. Ekstrom in litt., 2003). Olive white-eyes are monogamous and solitary and range over large areas in search of nectar sources (Cheke, 1987b). Two previous surveys found the olive whiteeye to exist in low numbers with a small, localized distribution. During the first survey in 1975, the total population was estimated at 346 pairs, the majority located in south-west Mauritius, with 20 pairs in central Mauritius (Cheke, 1987b). A second survey in 1993 estimated that the total population had declined to 200 pairs with only a few sightings observed outside south-west Mauritius (Safford, 1997b). A third survey was carried out between November 1998 and February 2001. This paper reports the findings of that survey and suggests appropriate species-specific management techniques to prevent a further decline in numbers and distribution. 


\section{Methods}

\section{Study area}

The surveys were carried out in the same areas of southwest Mauritius that had been surveyed between 1973 and 1975 (Cheke, 1987b) and between 1989 and 1994 (Safford, 1997b). Both of these previous surveys found outlying olive white-eye territories in central Mauritius (Montagne Lagrave and the 'central plateau relicts'). As these areas could not be surveyed during the present study we therefore used the population estimates from the 1993 survey. All other areas that had been surveyed by Cheke and Safford were revisited.

The forest in the study area of south-west Mauritius consisted mainly of exotic vegetation, degraded native forest, and softwood tree plantations (Fig. 1). The most common introduced plant species in areas of exotic and degraded native vegetation included Psidium cattleianum, Ligustrum robustum, Ravenala madagascariensis, Syzigium jambos, Rubus alceifolius and Lantana camara. Monvert, Florin, Pétrin and Bois Sec were small nature reserves containing native forest. Tree plantations consisted mainly of Pinus elliotti and to a lesser extent Eucalyptus robusta and Melaleuca quinquenervia, with smaller patches of Cryptomeria japonica, Araucaria spp. and Callistemon citrinus.

\section{Survey technique and coverage}

Territory mapping followed the methodology of Safford (1997b) and allowed a direct comparison with the 1993 survey. The surveys were carried out during the breeding season (September-March) when olive white-eyes were most conspicuous (Cheke, 1987b). Territorial birds were located and their territories mapped, beginning with the areas of highest density as found by Safford (1997b). Separate territories were determined by locating disputing individuals and pairs and by locating pairs exhibiting nesting behaviour. Distinguishing territorial birds was easiest during the dawn chorus (04.30-06.30).

The survey covered 16 areas of native vegetation. Survey coverage varied due to the patchy distribution of the population (Table 1). The coverage categories

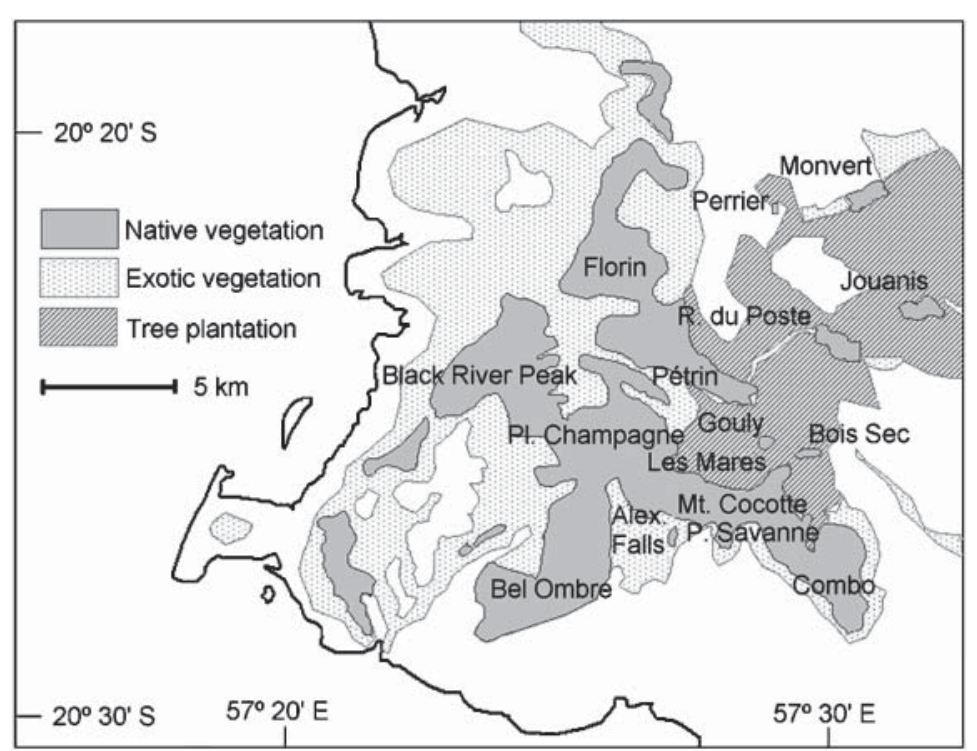

Fig. 1 South-west Mauritius showing vegetation types and area names referred to in the text (adapted from Safford, 1997a). Montagne Lagrave was an isolated $4.0 \mathrm{~km}^{2}$ patch of degraded native forest located approximately $6.6 \mathrm{~km}$ north-east of Monvert.

Table 1 Coverage of areas surveyed for the Mauritius olive white-eye Zosterops chloronothos between 1998 and 2001. Good and Fair coverage are areas that received more or less than $8 \mathrm{~h} \mathrm{~km}^{-2}$, respectively.

\begin{tabular}{|c|c|c|c|}
\hline Areas surveyed & Hours & Effort $\left(\mathrm{h} \mathrm{km}^{-2}\right)$ & Assessment of coverage \\
\hline Bois Sec/Rivière du Poste & 50 & 22.6 & Good \\
\hline Florin/Pétrin/Gouly & 64 & 18.3 & Good \\
\hline Monvert/Jouanis/Perrier & 21 & 7.6 & Fair \\
\hline Black River Peak/Plaine Champagne/Bel Ombre & 142 & 7.8 & Fair \\
\hline Alexandra Falls/Piton Savanne/Montagne Cocotte & 201 & 36.8 & Good \\
\hline Combo & 96 & 24.0 & Good \\
\hline Les Mares & 176 & 58.6 & Good \\
\hline
\end{tabular}


followed those of Safford (1997b). Coverage was considered 'good' when the total effort in an area exceeded $8 \mathrm{~h} \mathrm{~km}^{-2}$. Any area with effort below this was considered to have received 'fair' coverage. All areas that contained the highest numbers of pairs in the earlier surveys received good coverage in the present study. Fair coverage was considered to be sufficiently intensive to ensure the detection of presence or absence of olive white-eyes within an area (as found by Safford, 1997b). Population estimates are given as the number of territorial pairs. The total number of pairs within an area was estimated by extrapolating the number of territories recorded in surveyed areas to adjacent areas of non-surveyed similar habitat (following Cheke, 1987b, and Safford, 1997b).

\section{Results}

\section{Population status and distribution in 2001}

We located 67 territories in the 2001 survey, giving a total estimated population of 93-148 pairs (Table 2). The distribution of the Mauritius olive white-eye has contracted significantly (Fig. 2). The entire population was restricted to an area of $<25 \mathrm{~km}^{2}$, with the exception of a few pairs possibly remaining at Montagne Lagrave and the 'central plateau relicts'.

Of the outlying sub-populations, the area of Jouanis has been clear-felled and the two olive white-eye territories found in 1993 no longer exist. The three territories recorded at Florin in 1993 have also disappeared. No olive white-eyes were recorded from areas where single or occasional sightings were reported in 1993. Only a single outlying sub-population remained in 2001, between Pétrin and Rivière du Poste (Fig. 2).

The core sub-population was distributed between Alexandra Falls and Combo and, with the exception of Combo, all areas contained considerably fewer territories in 2001 (Table 2). Nearly all of the 153 territories estimated for the Black River Peak - Bel Ombre area in 1975 have disappeared, with only two territories found in 2001. Four new territories were found in Les Mares representing a slight range expansion into pine plantation.

Olive white-eye territories have declined most notably in areas dominated by native vegetation, including Black River Peak - Bel Ombre, Piton Savanne-Montagne Cocotte and Florin - Gouly. The number of territories in Bois Sec, Rivière du Poste and Combo, which are dominated or surrounded by exotic C. japonica and $P$. ellioti, have remained relatively stable.

\section{Discussion}

The Mauritius olive white-eye is the most challenging of the Mauritian passerines to accurately census due to the species' elusive and quiet nature (Cheke, 1987a; Safford, 1997b). Although population estimates may be tentative (Safford, 1997b), distribution limits can be determined with greater precision and more accurately compared among surveys (Bibby et al., 1992). Over the past 25 years the population distribution of the olive white-eye has contracted. Three outlying sub-populations have disappeared and the core area has decreased by nearly $50 \%$ since 1975. The near-extirpation of olive white-eyes from

Table 2 Distribution and population estimates of the Mauritius olive white-eye Zosterops chloronothos in 1975, 1993 and 2001. Data for 1975 and 1993 are from Safford (1991, in. litt. 2001).

\begin{tabular}{|c|c|c|c|c|c|}
\hline Area & Pairs estimated 1975 & $\begin{array}{l}\text { Pairs found } \\
1992 / 1993\end{array}$ & $\begin{array}{l}\text { Pairs estimated } \\
1992 / 1993\end{array}$ & $\begin{array}{l}\text { Pairs found } \\
2000 / 2001\end{array}$ & $\begin{array}{l}\text { Pairs estimated } \\
2000 / 2001\end{array}$ \\
\hline \multicolumn{6}{|l|}{ Outlying sub-populations } \\
\hline Bois Sec/Rivière du Poste & 11 & 18 & $20-25$ & 7 & $10-14$ \\
\hline Florin/Pétrin/Gouly & 22 & 5 & $6-12$ & 2 & $4-7$ \\
\hline $\begin{array}{l}\text { Monvert/Jouanis/Perrier/ } \\
\text { Montagne Lagrave }{ }^{1} / \\
\text { 'central plateau relicts' }{ }^{1}\end{array}$ & 19 & 5 & $15-30$ & 0 & $5-15$ \\
\hline \multicolumn{6}{|l|}{ Core sub-populations } \\
\hline $\begin{array}{l}\text { Black River Peak/ } \\
\text { Plaine Champagne/Bel Ombre }\end{array}$ & 153 & 18 & $30-100$ & 2 & $5-22$ \\
\hline $\begin{array}{l}\text { Alexandra Falls/Piton Savanne/ } \\
\text { Montagne Cocotte }\end{array}$ & 93 & 41 & $51-68$ & 31 & $40-54$ \\
\hline Combo & 25 & 3 & $15-25$ & 21 & $25-30$ \\
\hline Areas cleared since $1975^{2}$ & 23 & 0 & 0 & $4^{3}$ & $4-6$ \\
\hline Total & 346 & 90 & $137-260$ & 67 & $93-148$ \\
\hline
\end{tabular}

${ }^{1}$ Area not surveyed in 2001

${ }^{2}$ Areas cleared since 1975 are represented by 'Tree plantation' in Fig. 1

${ }^{3}$ Found in the pine plantation of Les Mares 


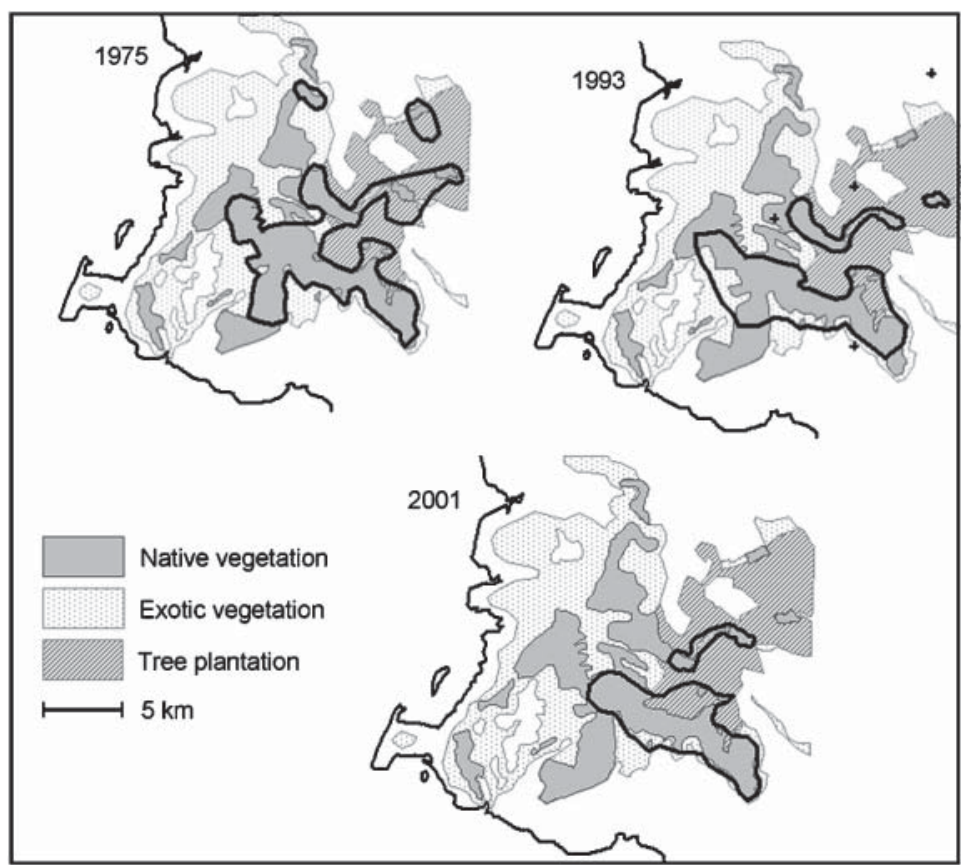

Fig. 2 The population ranges of the Mauritius olive white-eye Zosterops chloronothos (within solid black line) in 1975, 1993 and 2001. Data for 1975 and 1993 were reproduced from Cheke (1987b) and Safford (1997b). The small patch of native vegetation at Rivière du Poste was not surveyed in 1975. The + symbol refers to single sightings. Outlier sightings of olive white-eyes were further east during the 1975 and 1993 surveys. These sightings are not shown on this map but are reported in Table 2 . large areas is indicative of a continued severe decline in the species and is similar to the pattern of decline of the Mauritius fody Foudia rubra (Nichols et al., 2002; R.Safford unpubl. data).

Continued habitat loss and degradation and high levels of nest predation by introduced species appear to be the main factors in the continued decline of the Mauritius olive white-eye. Approximately 3,000 ha of endemic Pandanus marsh forest in south-west Mauritius were clear-felled between 1970 and 1975 and replaced with tree plantations. This was an important source area of endemic birds for much of the high plateau (Cheke, 1987a). Although major forest clearances of the same scale have not occurred since, native forest continues to be clear-felled on a smaller scale (e.g. the loss of Jouanis) and to rapidly degrade as a result of introduced invasive species, primarily P. cattleianum and L. robustum (Lorence \& Sussman, 1986). Forest communities dominated by these exotics generally provide poorer habitat, with less choice of foraging opportunities for nectarivores, than that of the more diverse native forest (Cheke 1987b; Safford, 1997b). Nest predation by introduced mammals has been a major factor in the decline of Mascarene passerines (Cheke, 1987b). Predation by the introduced ship rat Rattus rattus and the crab-eating macaque Macaca fascicularis was responsible for 83-95\% of nesting failures in the Mauritius fody (Safford, 1997c). Nest predation by the ship rat and Indian myna Acridotheres tristis has also been identified as the main reason for the decline of the Seychelles white-eye Zosterops modestus on the island of Mahé (Rocamora \& François, 2000).
The number of olive white-eye territories have remained stable in forest dominated or surrounded by exotic C. japonica and P. elliotti, but have declined in areas with a dominant native component. This pattern appears to be strongly associated with lower levels of nest predation by introduced predators in these exotic conifers. Nesting success was found to be significantly higher for Mauritius fody in C. japonica (46\%) than in other tree species $(6 \%)$, including native species (Safford, 1997c). Several species of Mauritian birds including the pink pigeon, the Mauritius fody, the Mascarene paradise flycatcher Terpsiphone bourbonnensis and the Mauritius black bulbul Hypsipetes olivaceous nest in exotic trees even when native trees are readily available (Safford, 1997c; Nichols, 2001). Stands of exotic conifers, such as C. japonica and P. elliotti, may be avoided as foraging areas by the ship rat and crab-eating macaque due to the relatively poor food availability. The role of exotic trees in the productivity and nestling survival of the Mauritius olive white-eye should be investigated further as it undoubtedly has important implications for future conservation.

\section{Conservation needs}

The following species-specific recommendations should be viewed in the context of conservation of the Mauritian ecosystem as a whole. Methodologies for rehabilitation of the native forest and large-scale predator control using predator-proof fences are currently being tested in Mauritius. However, without active management, 
the Mauritius olive white-eye will continue to decline and may go extinct before these long-term measures are successful. We make the following species-specific recommendations:

Protect existing wild breeding populations

Important known breeding areas of the olive white-eye need to be intensively protected from introduced nest predators by using predator-specific methods of control such as live-trapping or poisoning (Jones et al., 1992) and by predator-proofing individual nest sites (Harper et al., 1999) to provide source areas for the species.

\section{Improve food sources in the wild}

In the absence of management, continued habitat degradation will reduce the already limited nectar sources available to the olive white-eye. This can be addressed immediately by planting appropriate fast growing native flora and/or non-invasive exotics within the current range of the olive white-eye. Several species have previously been suggested including the native Trochetia uniflora and T. blackburniana and the exotic C. citrinus (Cheke, 1987b; Safford, 1991). Planting of exotics for conservation purposes should only be undertaken after a risk assessment to address the potential of each species to be invasive. Artificial nectar feeders should also be developed and provided in the short-term and in areas where planting nectar sources would not be possible. Supplemental feeding has been a successful conservation tool in significantly increasing the population numbers and distribution of the endemic kestrel, pigeon and parakeet and should be adapted for the olive white-eye.

\section{Establish new wild populations}

The translocation of breeding pairs to areas outside the core population, such as offshore islands, has been suggested by Safford \& Jones (1998). Inter-island translocations of the Seychelles white-eye have been successful, with translocated birds establishing breeding territories and producing fledglings within 6 months of translocation (Rocamora et al., 2002). Adult olive white-eyes range over large areas and may not remain after translocation, unless the new area can meet all the whiteeyes' requirements (A. Cheke unpubl. data), although the use of artificial nectar feeders and/or planted nectar sources may help ensure site fidelity to new areas. Avian diseases appear to be more prevalent in lowland species in Mauritius (Peirce et al., 1977) and translocation of upland species to offshore islands may expose birds to new pathogens (Cheke, 1987b; Safford \& Jones, 1998). Potential disease risks must be assessed before translocations are carried out.
The use of breeding enclosures situated within the upland forest would be the most cost effective and productive method of re-establishing wild populations in areas of their historic range. Field enclosures have been developed and successfully used for captive breeding and release of passerines (Woolaver \& Nichols, 2002) and could easily be adapted for the olive white-eye in Mauritius. This would allow captive, parent-raised individuals to be released in their natal area, increasing site fidelity. Releases would need to be done in conjunction with predator control and the provision of additional food sources, or within predator-proof restored areas.

\section{Establish captive population}

Small, localized populations are at a high risk of extinction (Simberloff, 1995). Establishment of several pairs in captivity should be a priority in the near future, particularly at this point in time when the wild population can still support the removal of a few pairs to captivity. Although a large-scale ex-situ captive breeding programme is not recommended for this species at the moment, a safeguard population should be established in captivity because a stochastic event could potentially have a dramatic effect on the remaining wild population.

\section{Acknowledgements}

The Ruth Smart Foundation, United Arab Emirates Natural History Group and Durrell Wildlife Conservation Trust provided financial support for the passerine research on Mauritius. The authors are grateful to Yousoof Mungroo, Mario Allet and Paul Moollee of the National Parks and Conservation Service of Mauritius for their continued support. Dedicated volunteers and staff of the Mauritian Wildlife Foundation helped during field surveys with Malcolm Burgess, Angela Duffy, Richard Lewis, Peter Phillips, Niall McCann, and Kenneth Sutcliffe contributing significantly. This manuscript was improved by the comments of Roger Safford, Anthony Cheke, Gérard Rocamora, and two anonymous reviewers.

\section{References}

Bibby, C.J., Burgess, N.D. \& Hill, D.A. (1992) Bird Census Techniques. Academic Press, London, UK.

BirdLife International (2000) Threatened Birds of the World. BirdLife International, Cambridge, UK.

Cheke, A.S. (1987a) An ecological history of the Mascarene Islands, with particular reference to extinctions and introductions of land vertebrates. In Studies of Mascarene Island Birds (ed. A.W. Diamond), pp. 5-89. Cambridge University Press, Cambridge, UK.

Cheke, A.S. (1987b) The ecology of the smaller land birds of Mauritius. In Studies of Mascarene Island Birds (ed. A.W. Diamond), pp. 151-207. Cambridge University Press, Cambridge, U.K. 
Harper, G., Woolaver, L., Birch, D., Jackson, D. \& Burgess, M. (1999) Management of the echo parakeet in the wild, 1998/1999. In Echo Parakeet Management Report 1999 (ed. L.G. Woolaver), pp. 29-61. Unpublished Report for the World Parrot Trust, UNDP, Durrell Wildlife Conservation Trust, National Parks and Conservation Service of Mauritius and the Mauritian Wildlife Foundation, Mauritius.

IUCN (2003) 2003 IUCN Red List of Threatened Species. IUCN, Gland, Switzerland [http:/ / www.redlist.org, accessed 2 March 2004].

Jones, C.G., Swinnerton, K.J., Taylor, C.J. \& Mungroo, Y. (1992) The release of captive-bred pink pigeons Columba mayeri in native forest in Mauritius. Dodo, Journal of the Wildlife Preservation Trust, 28, 92-125.

Jones, C.G., Heck, W., Lewis, R.E., Mungroo, Y., Slade, G. \& Cade, T. (1995) The restoration of the Mauritius kestrel population. Ibis, 137, 173-180.

Lorence, D.H. \& Sussman, R.W. (1986) Exotic species invasion into Mauritius wet forest remnants. Journal of Tropical Ecology, 2, 147-162.

Maunder, M., Page, W., Mauremootoo, J., Payendee, R., Mungroo, Y., Maljkovic, A., Vericel, C. \& Lyte, B. (2002) The decline and conservation management of the threatened endemic palms of the Mascarene Islands. Oryx, 36, 56-65.

Nichols, R.K. (2001) Endangered Passerines on Mauritius, Management Report 2000/2001. Unpublished report to the Ruth Smart Foundation, United Arab Emirates Natural History Group, Durrell Wildlife Conservation Trust, National Parks and Conservation Service of Mauritius and Mauritian Wildlife Foundation. Black River, Mauritius.

Nichols, R.K., Phillips, P., Jones, C.G. \& Woolaver, L.G. (2002) Status of the critically endangered Mauritius fody Foudia rubra in 2001. Bulletin of the African Bird Club, 9, 95-100.

Page, W. \& D'Argent, G. (1997) A Vegetation Survey of Mauritius to Identify Priority Rainforest Areas for Conservation Management. Unpublished report for Mauritian Wildlife Foundation, Mauritius.

Peirce, M.A., Cheke, A.S. \& Cheke, R.A. (1977) A survey of blood parasites of birds in the Mascarene Islands, Indian Ocean, with descriptions of two new species and taxonomic discussion. Ibis, 119, 451-461.

Rocamora, G. \& François J. (2000) Seychelles White-eye Recovery Program. Phase 1 (May 1998-May 2000). Final Report. Ministry of Environment \& Transport/IUCN/Dutch Trust Fund, Republic of Seychelles.

Rocamora, G., Henriette, E., Constance, P., François, J. \& Fanchette, R. (2002) Successful inter-island transfers of Seychelles white-eyes. World Birdwatch, 24, 6 .
Safford, R.J. (1991) Status and ecology of the Mauritius fody Foudia rubra and Mauritius olive white-eye Zosterops chloronothos: two Mauritian passerines in danger. Dodo, Journal of the Wildife Preservation Trust, 27, 113-138.

Safford, R.J. (1997a) A survey of the occurrence of native vegetation remnants on Mauritius in 1993. Biological Conservation, 80, 181-188.

Safford, R.J. (1997b) Distribution studies on the forest-living native passerines of Mauritius. Biological Conservation, 80, 189-198.

Safford, R.J. (1997c) Nesting success of the Mauritius fody, Foudia rubra, in relation to its use of exotic trees as nest sites. Ibis, 139, 555-559.

Safford, R.J. \& Jones C.G. (1998) Strategies for land-bird conservation on Mauritius. Conservation Biology, 12, 169-176.

Simberloff, D. (1995) Habitat fragmentation and population extinction of birds. Ibis, 137, 105-111.

Thorsen, M. \& Jones, C.G. (1998) The conservation status of echo parakeet Psittacula eques of Mauritius. Bulletin of the African Bird Club, 5, 122-126.

Woolaver, L. \& Nichols, R. (2002) Captive Field Propagation and Experimental Release of Eastern Loggerhead Shrike in Ontario, 2002. Unpublished Report to the Wildlife Preservation Trust Canada. Guelph, Canada.

\section{Biographical sketches}

Rina Nichols was the Passerine Project Coordinator for the Mauritian Wildlife Foundation between 1998 and 2001. During this time she also supervised releases of threatened pink pigeons and echo parakeets. She has most recently been working with threatened small carnivores in Canada and Madagascar.

Lance Woolaver was the Fauna Conservation Manager for the Mauritian Wildlife Foundation between 1998 and 2001. During the same time period, he was also the Project Coordinator for the echo parakeet for which he developed and carried out reintroduction techniques. He has also worked with threatened species in Canada, New Zealand, Madagascar, and most recently, California. He is a member of the IUCN/SSC Reintroduction Specialist Group.

Carl Jones is the Scientific Director of the Mauritian Wildlife Foundation. 